\title{
Induction of a heat shock-like response by unfolded protein in Escherichia coli: dependence on protein level not protein degradation
}

\author{
Dawn A. Parsell and Robert T. Sauer
}

Department of Biology, Massachusetts Institute of Technology, Cambridge, Massachusetts 02139 USA

\begin{abstract}
To test the idea that unfolded protein might act as an intracellular signal for induction of the heat shock response in Escherichia coli, we examined the synthesis of several heat shock proteins after expression of an unfolded variant of the amino-terminal domain of $\lambda$ repressor. These experiments show that expression of a single mutant protein, and not its wild-type counterpart, is sufficient to induce a heat shock-like response. In addition, by measuring the abilities of unfolded variants of differing proteolytic susceptibilities to induce heat shock protein synthesis and by monitoring heat shock protein synthesis as a function of the amount of a single unfolded protein, we show that it is the concentration of unfolded protein in the cell, and not its degradation, that is important for inducing the heat shock-like response.
\end{abstract}

[Key Words: Heat shock response; unfolded protein; protein degradation; Escherichia coli; $\lambda$ repressor]

Received February 23, 1989; revised version accepted May 23, 1989.

Escherichia coli, like most organisms, responds to an increase in temperature by increasing the synthesis of a set of proteins called heat shock proteins (HSPs; for review, see Neidhardt et al. 1984). Treatment of cells with other stressors such as ethanol and hydrogen peroxide also induces some or all of the heat shock proteins (VanBogelen et al. 1987).

A key regulator of the heat shock response is $\sigma^{32}$, the product of the $h t p R$ gene, which functions as an RNA polymerase subunit to direct transcription from specific heat shock promoters (Grossman et al. 1984). After heat shock, the intracellular level of $\sigma^{32}$ increases, resulting in elevated transcription of HSP genes (Straus et al. 1987). At present, it is not certain how heat shock and other stress treatments are coupled to increased transcription by $\sigma^{32}$. Because many of the inducing treatments can lead to protein damage or denaturation, it has been suggested (Goff and Goldberg 1985) that production of unfolded polypeptides may be a universal signal for induction of the heat shock response. In fact, HSP induction occurs after treatment of $E$. coli cells with amino acid analogs and puromycin, which are thought to increase the intracellular concentration of unfolded protein, and after expression of certain 'foreign' proteins whose rapid degradation is taken as evidence for an unfolded structure (Goff and Goldberg 1985).

In the experiments reported here, we test directly the idea that unfolded protein can act as a signal for induction of heat shock proteins. Using the amino-terminal domain of $\lambda$ repressor, a protein of known structure (Pabo and Lewis 1982), we show that expression of an unfolded, mutant polypeptide and not its folded, wildtype counterpart is sufficient to induce a heat shock-like response in $E$. coli. Moreover, we show that HSP induction does not depend on the degradation of unfolded protein, but rather, on its intracellular concentration. This suggests a direct role for the unfolded protein in the induction process.

\section{Results}

Folded and unfolded variants of the amino-terminal domain

To test the idea that expression of unfolded protein is sufficient to induce a heat shock-like response, we use two variants of the amino-terminal domain of $\lambda$ repressor. The wild-type fragment is designated $\mathrm{N}^{102 L T}$. The amino-terminal 92 residues of this fragment (128 residues total) fold into a stable, predominantly $\alpha$-helical, three-dimensional structure, whose stability can be monitored by changes in circular dichroism. As shown in the thermal denaturation experiment of Figure 1 , the $\alpha$-helical portion of the wild-type $\mathrm{N}^{102 L T}$ protein is 


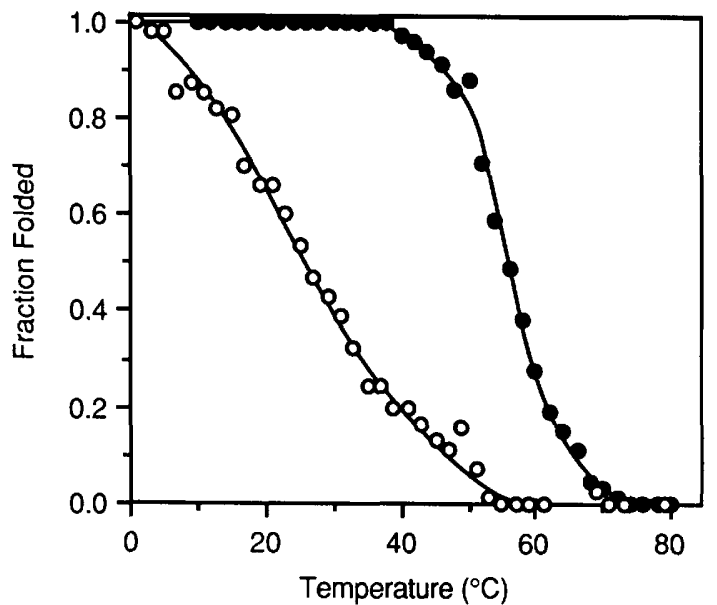

Figure 1. Thermal denaturation of wild-type and mutant forms of the amino-terminal domain variants. The fraction of each protein in the folded form was determined at $2^{\circ} \mathrm{C}$ intervals over the temperature ranges shown from circular dichroism measurements at $222 \mathrm{~nm}$. $(\bullet) \mathrm{N}^{102 L \mathrm{r}}$; (O) LA57-N $\mathrm{N}^{102 L T}$.

folded stably at $37^{\circ} \mathrm{C}$ and unfolds with a $T_{\mathrm{m}}$ near $55^{\circ} \mathrm{C}$. A mutant form of this fragment, designated LA57- $\mathrm{N}^{102 L T}$, contains a single amino acid substitution ( $\mathrm{Leu}^{57} \rightarrow \mathrm{Ala}$ ), which reduces its $T_{\mathrm{m}}$ to $\sim 25^{\circ} \mathrm{C}$ (Fig. 1). At $37^{\circ} \mathrm{C}$ the $\alpha$-helical portion of this mutant protein is unfolded in $\sim 80 \%$ of the molecules. Because the amino-terminal domain of $\lambda$ repressor contains no disulfide bonds and because the experiments shown in Figure 1 were conducted at roughly physiological $\mathrm{pH}$ and ionic strength, the estimate of the fraction of protein in the unfolded form should be a reasonable approximation of that found in vivo (Parsell and Sauer 1989).

\section{Expression of unfolded protein induces a heat shock-} like response

In separate experiments, tac promoter-mediated expression of the wild-type and mutant forms of the $\mathrm{N}^{102 L T}$ protein was induced by addition of isopropyl-thio- $\beta$-Dgalactoside (IPTG), and synthesis of $E$. coli proteins was monitored by 2 -min $\left[{ }^{35} S\right]$ methionine pulses at intervals thereafter. Expression of the thermally unstable mutant results in increases in the synthesis rates of several heat shock proteins including GroEL, DnaK, and C62.5, as shown in Figure 2A. Increased synthesis of a lacZ fusion protein from the $\mathrm{P}_{h t p G}$ heat shock promoter also is induced by expression of the unfolded protein. No significant increase in the synthesis of heat shock proteins is observed when expression of the folded $\mathrm{N}^{102 \mathrm{LT}}$ protein is induced with IPTG (Fig. 2B). This latter result indicates that the increased synthesis of heat shock proteins in the former case is not caused directly by the addition of IPTG or indirectly via expression of proteins other than LA57-N ${ }^{102 L T}$ whose synthesis might be under IPTG control. Thus, the expression of a single, predominantly unfolded protein is sufficient to induce a heat shock-like response.
As shown in Figure 2A, increased heat shock protein synthesis is evident $10 \mathrm{~min}$ after IPTG addition, with synthesis rates increasing somewhat at 20 and $30 \mathrm{~min}$. In experiments not shown, we observed that HSP synthesis reached a plateau 25-40 min after addition of IPTG and then remained constant until $60 \mathrm{~min}$ (the longest time tested). The experiment shown in Figure 2 was performed at $37^{\circ} \mathrm{C}$. Experiments performed at $30^{\circ} \mathrm{C}$ gave similar results. Also, we found that HSP induction did not depend on the particular destabilizing mutant substitution (Leu ${ }^{57} \rightarrow \mathrm{Ala}$ ) used for these studies. Other destabilizing substitutions at position 57 (e.g., Gly, Cys, Pro, and Arg) or at other hydrophobic core positions (e.g., $\mathrm{Leu}^{69} \rightarrow \mathrm{Arg}$ or Glul also resulted in proteins whose expression induced increased HSP synthesis /data not shown).

Neither overproduction of the plasmid-borne repressor proteins nor the resulting induction of heat shock proteins in the case of the unfolded mutant appears to be deleterious to the cell. As shown in Figure 3, no significant changes in growth rate can be detected for several generations after IPTG induction of the wildtype or mutant amino-terminal domain proteins. We also examined the induction of HSPs after the expression of unfolded protein in isogenic $\mathrm{lon}^{+}$and lon $^{-}$ strains and $h t p R^{+}$and $h t p R^{-}$strains. Although deletion of the lon gene had no effect on the ability of the LA57$\mathrm{N}^{102 L T}$ protein to induce increased HSP synthesis, an amber mutation in the $h t p R$ gene (suppressed by a temperature-sensitive suppressor at $30^{\circ} \mathrm{C}$ ) prevented this induction (data not shown). Although some $\sigma^{32}$ may be present in the $h t p R^{-}$strain at $30^{\circ} \mathrm{C}$, the absence of induction of HSPs after expression of the LA57- $\mathrm{N}^{102 L T}$ protein suggests that $\sigma^{32}$ or a protein under $\sigma^{32}$ control is required at some step for the heat shock-like response. On the other hand, the product of the lon gene, protease $\mathrm{La}$, clearly is not required for the ability of unfolded LA57-N ${ }^{102 L T}$ to induce HSP synthesis.

\section{HSP induction does not depend on the rapid degradation of unfolded protein}

Is HSP induction dependent on the concentration of unfolded protein or on the degradation of this protein? To address this issue, we used the amino-terminal domain variants LA57- $\mathrm{N}^{102 \mathrm{LT}}$ and LA57-N $\mathrm{N}^{92}$. Both of these proteins contain the same 92 amino-terminal amino acids, which are predominantly unfolded at $37^{\circ} \mathrm{C}$ because each contains the LA57 mutation (Fig. 1; Parsell and Sauer 1989). However, as shown in the pulse-chase experiments of Figure 4, the proteins have different intracellular half-lives. The LA57-N ${ }^{102 L T}$ protein is quite stable with a half-life of $>3 \mathrm{hr}$, whereas the LA57- $\mathrm{N}^{92}$ protein is degraded rapidly with a half-life of $\sim 6 \mathrm{~min}$. We have shown previously that the different intracellular stabilities of these proteins arise because they have different carboxy-terminal sequences (Bowie and Sauer 1989; Parsell and Sauer 1989|. Compared with the $\mathrm{N}^{92}$ protein, the $\mathrm{N}^{102 L T}$ protein has a 38-residue carboxy-terminal extension. 
Figure 2. Synthesis of heat shock proteins after expression of unfolded and folded proteins. At time zero (0), $1 \mathrm{~mm}$ IPTG was added to logarithmic-phase cells of strain DP700 (grown at $37^{\circ} \mathrm{C}$ ) bearing plasmids encoding either the predominantly unfolded (LA57$\mathrm{N}^{102 L T}$ ) or folded $\left(\mathrm{N}^{102 L T}\right)$ protein, and aliquots were pulse-labeled for $2 \mathrm{~min}$ at intervals thereafter. (Lane $H S)$ An uninduced culture of LA57- ${ }^{102 L T}$ pulse-labeled $7 \mathrm{~min}$ after a temperature shift from $37^{\circ} \mathrm{C}$ to $42^{\circ} \mathrm{C}$. Induced heat shock proteins are indicated by arrows with the uppermost arrow showing the position of the fusion protein product made from the $P_{h t p G}$ promoter.

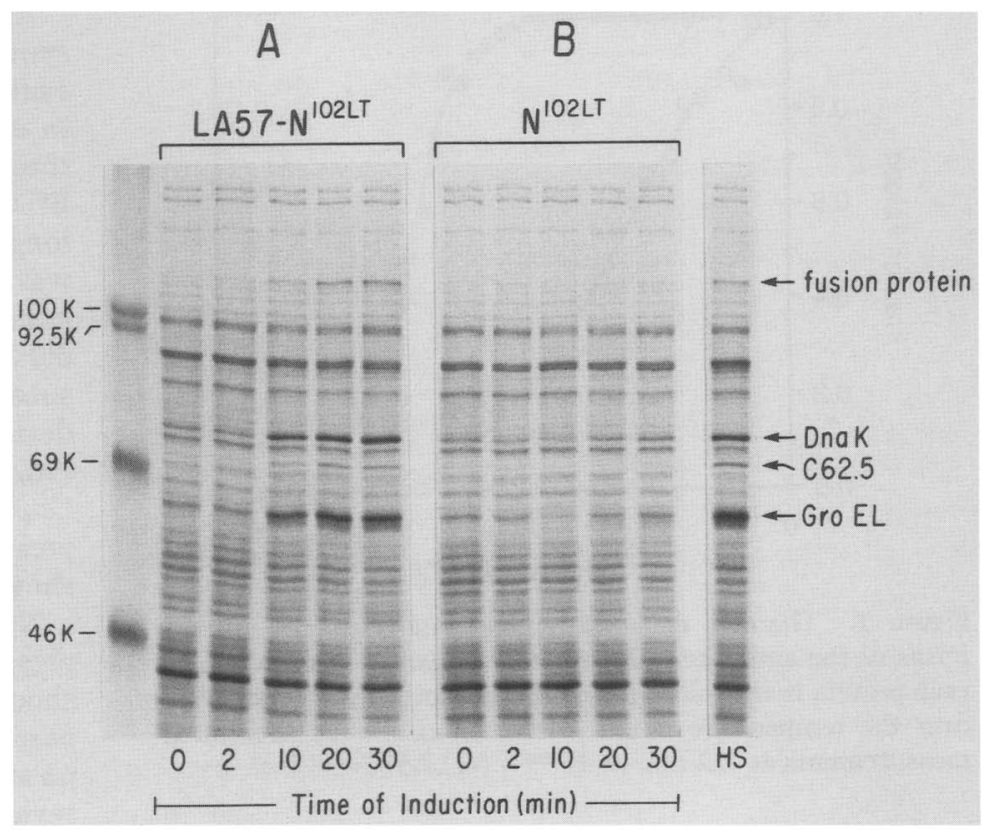

Expression of the two LA57 amino-terminal-domain variants induces HSP synthesis to differing extents. As shown in Figure 5, expression of the LA57- ${ }^{102 L T}$ protein induces HSP synthesis more efficiently than does expression of the LA57- $\mathrm{N}^{92}$ protein. Thus, there is an inverse correlation between degradation rates and the ability to induce HSP synthesis. The protein that has the longer intracellular half-life is the most effective at inducing HSP synthesis, whereas the protein that has the shorter half-life is the least effective. Both of the aminoterminal domain proteins are synthesized at approximately the same rate (data not shown); therefore, it seems likely that the LA57-N $\mathrm{N}^{102 L T}$ protein induces HSP synthesis more efficiently that the LA57- $\mathrm{N}^{92}$ variant simply because it is present at a higher level. Thus, HSP synthesis in $E$. coli appears to depend on the intracellular concentration of unfolded protein and not on the rapid degradation of that protein.

In principle, the different abilities of the LA57 variants to induce heat shock protein synthesis could be directly related to their different carboxy-terminal extensions. However, the carboxy-terminal residues of the LA57- $\mathrm{N}^{1022 \mathrm{~T}}$ protein also are present in the $\mathrm{N}^{102 \mathrm{LT}}$ protein, which does not induce heat shock protein synthesis (Fig. 2), even though it is present at a high steadystate level (data not shown). In the next section we test directly the idea that the induction of HSPs depends on the concentration of unfolded protein.
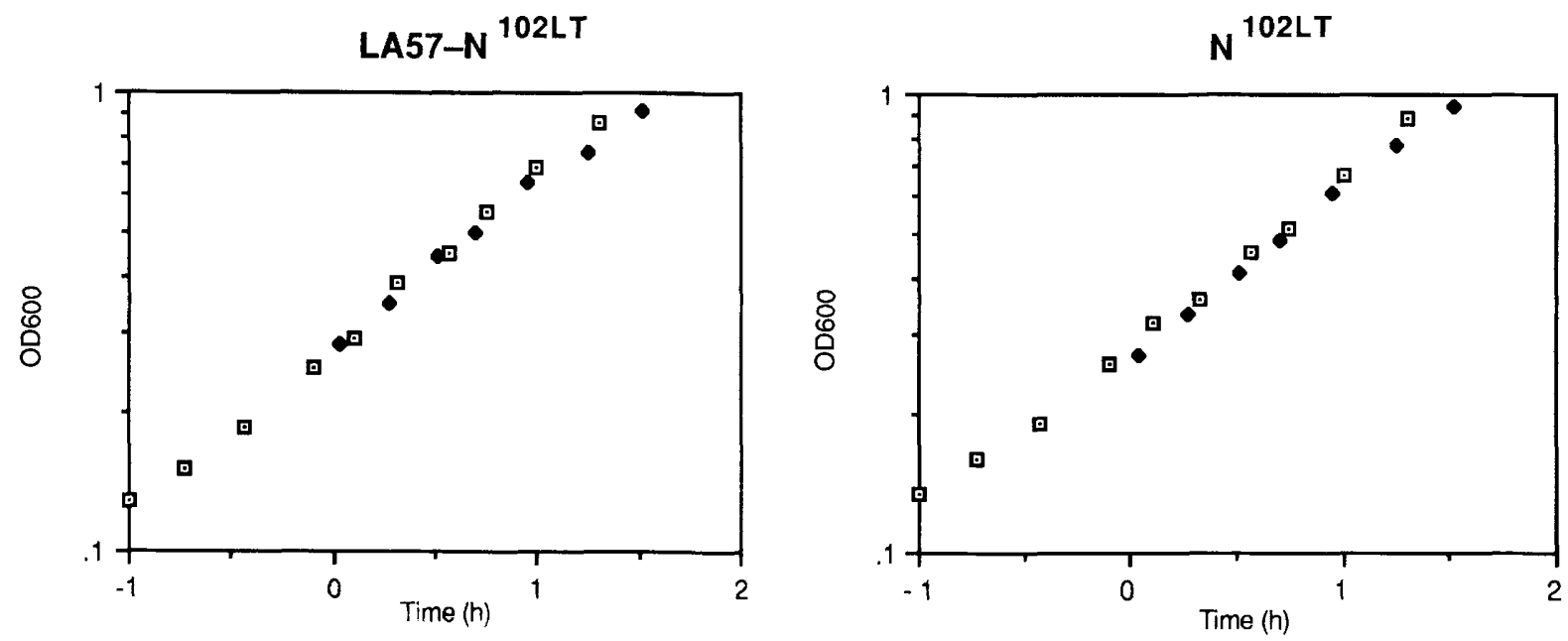

Figure 3. Expression of wild-type or mutant amino-terminal domain variants does not affect the growth of $E$. coli strain DP700. At $\mathrm{OD}_{600}=0.2-0.3$, logarithmic-phase cultures were split and expression of plasmid-encoded protein was induced with $1 \mathrm{mM}$ IPTG in half of the culture. ( $\square)$ Uninduced cells; $(\bullet)$ induced cultures. 


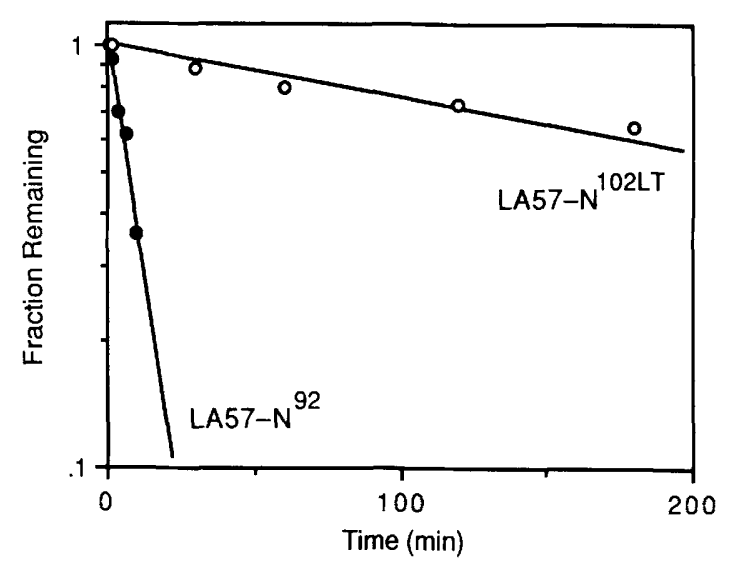

Figure 4. Degradation of LA57-N $\mathrm{N}^{102 \mathrm{LT}}$ and LA57- $\mathrm{N}^{92}$ in E. coli strain DP700. The fraction of pulse-labeled protein remaining at various times after a chase was determined by densitometry of autoradiographs.

\section{Induction of HSPs is directly correlated with the intracellular level of unfolded protein}

The dependence of HSP synthesis on the concentration of unfolded protein also can be seen when the level of a single protein is varied. In the experiments of Figure 6, tac promoter-mediated expression of the LA57- $\mathrm{N}^{102 \mathrm{LT}}$ protein was adjusted by varying the amount of IPTG present during a 30-min induction period. The cells then were pulse-labeled with $\left[{ }^{35} S\right]$ methionine and samples were electrophoresed and either autoradiographed to monitor protein synthesis (Fig. 6A) or Western-blotted to monitor accumulation of LA57-N ${ }^{102 L T}$ protein (Fig. 6B). Over the range of IPTG concentration shown, increased synthesis of heat shock proteins can be seen to occur concomitantly with increased levels of LA57-N ${ }^{102 L T}$ protein. We believe that these data and those shown in Figure 5 provide strong support for the idea that the level of unfolded protein present in the cell, and not its degradation, determines its ability to act as an inducer of heat shock protein synthesis.

\section{Discussion}

We have shown that the expression of a single unfolded polypeptide is sufficient to induce increased synthesis of heat shock proteins in $E$. coli. These experiments extend the work of other investigators (Goff and Goldberg 1985; Ito et al. 1986), which showed that expression of 'abnormal' polypeptides could induce heat shock protein synthesis. In addition, using variants of the amino-terminal domain of $\lambda$ repressor, we have shown that the ability of a given unfolded protein to induce HSP synthesis correlates with its intracellular concentration rather than its degradation rate. At present, we do not know whether all unfolded chains are equivalent in their ability to induce HSPs or whether there are specific sequence or structural elements that, in the context of an unfolded polypeptide, are recognized as signals for HSP induction.
Is an increase in the concentration of unfolded protein the normal physiological signal for induction of the heat shock response? This model is attractive for several reasons: (1) Increased levels of some unfolded proteins can induce a heat shock-like response; (2) many of the environmental treatments that induce heat shock could result in protein denaturation; and (3) recent studies suggest that some heat shock proteins may function by binding to unfolded polypeptides (Bochkareva et al. 1988). If heat shock proteins function, at least in part, to protect the cell from the deleterious effects of unfolded proteins, it would be appropriate that an increase in the concentration of unfolded protein could act as a signal for induction of the heat shock response.

The kinetics of HSP induction normally observed after a temperature increase differ from those observed here after expression of unfolded protein. After an increase in temperature, heat shock protein synthesis rises transiently, reaching a maximum after 5-7 $\mathrm{min}$, and then decreases to a new steady-state rate after 15-20 min (for review, see Neidhardt et al. 1987). Perhaps a temperature increase results in the unfolding of a set of proteins that act as a transient signal for HSP induction and then are proteolyzed rapidly by the degradative systems of the cell. In contrast, the increased synthesis of heat shock proteins that follows expression of the plasmid-borne unfolded protein studied here is not transient (see Figs. 2 and 5). Synthesis of heat shock proteins remains high at

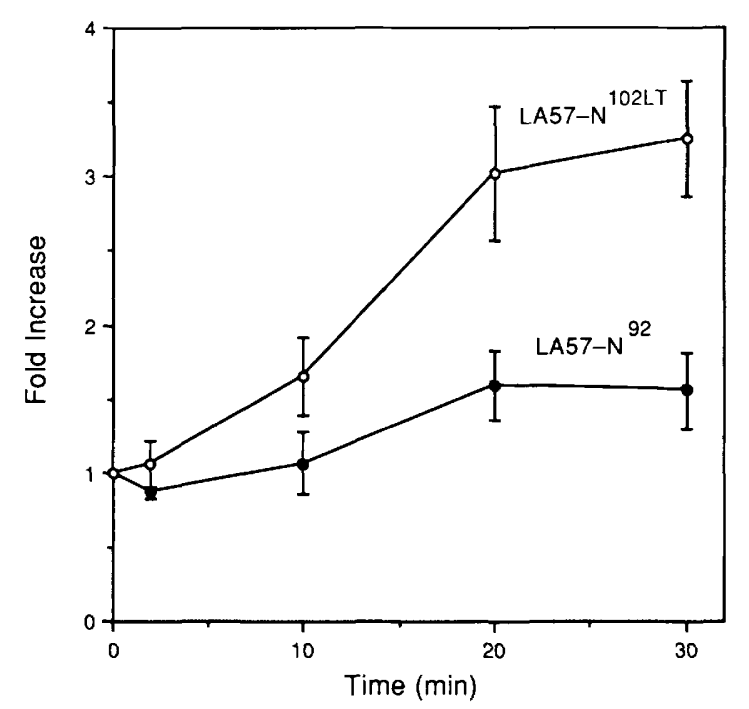

Figure 5. Synthesis of $l a c Z$ fusion protein made from heat shock promoter $\mathrm{P}_{h t p G}$ after expression of LA57- $\mathrm{N}^{102 L T}$ and LA57- $\mathrm{N}^{92}$. The amount of fusion protein synthesized during a 2-min pulse labeling at various times after IPTG addition was determined by densitometry of autoradiographs similar to those shown in Fig. 2. The amount of fusion protein present at each time was normalized to the amount of EFTu, a protein whose synthesis rate does not change as a result of IPTG addition. The mean values were determined from a set of three separate experiments, and error bars show the standard deviation of the data from the mean. The fusion protein is not degraded detectably during a 3 -hr pulse-chase experiment /data not shown). 


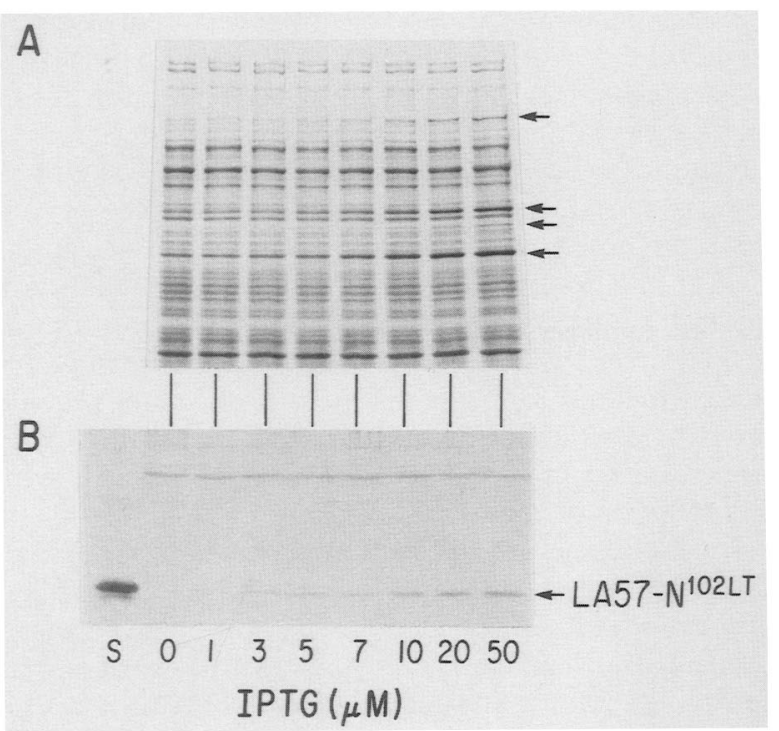

Figure 6. Synthesis of heat shock proteins as a function of the increasing level of unfolded protein. $(A)$ Logarithmic-phase cells of strain DP700 (grown at $37^{\circ} \mathrm{C}$ ) bearing a plasmid encoding the unfolded LA57- $\mathrm{N}^{102 \mathrm{~T}}$ protein were induced for $30 \mathrm{~min}$ with various concentrations of IPTG and then were pulse-labeled for 2 min. Induced heat shock proteins and the $\mathrm{P}_{h t p G}-1 a c Z$ fusion protein are indicated with arrows. $(B)$ The level of LA57-N $\mathrm{N}^{102 L T}$ protein (indicated with an arrow) present in the lysates described above was determined by Western blot analysis. (Lane S) $1 \mu \mathrm{g}$ of purified LA57-N ${ }^{102 L T}$ protein.

least $60 \mathrm{~min}$ after addition of IPTG /the latest time measured). In this case, increased HSP synthesis presumably persists because of the continuous overproduction of unfolded protein, the inducing signal.

Studies by Bahl et al. (1987) report immediate growth inhibition after induction of heat shock proteins by expression of the $\lambda$ cIII protein. They suggest that a prolonged heat shock response is deleterious and that the transient nature of the normal response may be essential (Bahl et al. 1987). In contrast, we found no significant effect on growth rate during the $2 \mathrm{hr}$ after heat shock protein synthesis was induced by unfolded protein. Therefore, it appears that prolonged expression of heat shock proteins is not immediately deleterious. Perhaps the growth inhibition observed with cIII is a result of some other aspect of its overexpression.

How might unfolded protein function in vivo as a signal for induction of the heat shock response? An increase in the concentration of $\sigma^{32}$, resulting from both a decrease in its degradation rate and an increase in its synthesis rate, is thought to be directly responsible for the increased level of heat shock protein synthesis seen during a heat shock (Straus et al. 1987). It has been suggested (Goff and Goldberg 1985; Straus et al. 1987; Goff et al. 1988) that unfolded proteins generated during a heat shock stabilize $\sigma^{32}$ indirectly by competing for intracellular proteases, such as protease $\mathrm{La}$, and thus decrease the degradation of $\sigma^{32}$. Our results suggest that if, indeed, this mechanism is operative, then unfolded pro- teins do not need to be degraded rapidly to compete for proteases. Moreover, our results show that protease $\mathrm{La}$ is clearly not required for the observed heat shock response.

We would like to suggest another possible mechanism for the induction of HSPs by the presence of unfolded protein. Namely, unfolded protein may bind to $\sigma^{32}$ directly and thereby affect its stability or activity, or it may affect an earlier step in the signal transduction process by binding to another protein that influences $\sigma^{32}$ activity. There is precedent for the idea that the action of a $\sigma$ factor can require other proteins and that environmental stress signals can act to regulate the activity of these proteins. For example, in enteric bacteria nitrogen starvation results in the phosphorylation of a regulatory protein that acts in concert with $\sigma^{54}$ to activate transcription from nitrogen-regulated promoters (for review, see Magasanik 1988).

\section{Methods}

\section{Nomenclature}

In this work two variants of the amino-terminal domain of $\lambda$ repressor are used. The variant designated $\mathrm{N}^{92}$ contains the first 92 residues of the $\lambda$ repressor (Sauer and Anderegg 1978). The $\mathrm{N}^{102 L T}$ variant contains the amino-terminal 102 residues of $\lambda$ repressor fused to the LT ('long tail'), sequence $\left(\mathrm{NH}_{2}\right.$-Lys-ValGlu-Ala-Pro-Thr-Ala-Val-Thr-Val-Arg-Ala-Ser-Val-Val-Ser-LysSer-Leu-Glu-Lys-Asn-Gln-His-Glu-COOH), described by Bowie and Sauer (1989). When the LT sequence is added to the carboxyl terminus of bacteriophage P22 Arc repressor, it stabilizes Arc against proteolysis in vivo, apparently by affecting the suitability of the protein as a substrate for proteases (Bowie and Sauer 1989). This extension also has been shown to protect mutants of the amino-terminal domain of $\lambda$ repressor from intracellular degradation (Bowie and Sauer 1989; this paper).

\section{Bacterial strains and plasmids}

The following $E$. coli K-12 strains were used in this work.

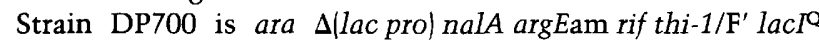
lacZ :: $\operatorname{Tn} 5\left(\operatorname{Kan}^{\mathbf{R}}\right) \mathrm{pro}^{+}$and is lysogenic for a $\lambda \mathrm{imm}^{21}$ phage, which carries a $\mathrm{P}_{\text {htp }}-l a c Z$ fusion (a gift from Dr. J. Wild). This strain phenotypically is $l a c Y^{-}$. Strain DP700 lon- was constructed by P1 transduction (Miller, 1972) of the lon :: $\Delta \operatorname{Tn} 10$ allele (Maurizi et al. 1985); strain CAG2039 (a gift from C. Gross) is ara $\Delta$ (lac prol thr trpam supCts $h t p R 165 \mathrm{am} / \mathrm{F}^{\prime}$ lac $I^{\mathrm{Q}}$ lacZ:: Tn5; strain CAG2041 (Grossman et al. 1987) is CAG2039 htpR+

The plasmids that encode the $\lambda$ repressor amino-terminal domain proteins are derivatives of plasmid pRB104. This is a pBR322 derivative containing an $\mathrm{Ml} 3$ origin of replication and a gene encoding residues $1-102$ of $\lambda$ repressor under transcriptional control of a tac promoter (Breyer 1988). The construction of the plasmid encoding the protein LA57- $\mathrm{N}^{92}$ has been described previously (Parsell and Sauer 1989). The plasmid encoding the protein $\mathrm{N}^{102 L \mathrm{~T}}$ was a gift from J. Bowie. The plasmid encoding the protein LA57-N ${ }^{102 L T}$ was constructed by ligating the 3.5-kb PstI-EcoRI fragment of the $\mathrm{N}^{102 L \mathrm{~T}}$ plasmid with the 1-kb EcoRI-PstI fragment of a plasmid encoding the LA57-N ${ }^{102}$ protein (Parsell and Sauer 1989), using standard techniques (Maniatis et al. 1982). To confirm that the constructions were correct, single-stranded plasmid DNA was purified 
from an M13RV1 transducing lysate (Vershon et al. 1986), and DNA sequences were determined using the dideoxy method (Sanger et al. 1977).

\section{Buffers}

Standard buffer (SB 100$)$ is $10 \mathrm{~mm}$ Tris- $\mathrm{HCl}(\mathrm{pH} 8), 2 \mathrm{mM} \mathrm{CaCl}_{2}$, $0.1 \mathrm{~mm}$ EDTA, $100 \mathrm{mM} \mathrm{KCl}$, and $5 \%$ glycerol (vol/vol) (SB15 and $S B 50$ contain 15 and $50 \mathrm{mM} \mathrm{KCl}$, respectively). Lysis buffer is $100 \mathrm{~mm}$ Tris- $\mathrm{HCl}(\mathrm{pH} 8), 1 \mathrm{~mm}$ EDTA, $10 \mathrm{~mm} 2$-mercaptoethanol, $500 \mathrm{mM} \mathrm{NaCl}, 6 \mathrm{M}$ urea, and $0.1 \% \mathrm{NP}-40$ (vol/vol).

\section{Protein purification}

Wild-type and mutant variants of the amino-terminal domain were purified from E. coli strain CAG2039 (relevant genotype $h t p R^{-}$), bearing appropriate overproducing plasmids, using a modification of the general method of Sauer et al. (1986). Cells were sonicated in cold lysis buffer, polyethyleneimine was added to $0.5 \%$ [from a $10 \%$ stock ( $\mathrm{vol} / \mathrm{vol}$ ) at $\mathrm{pH} 8$ ], and the sonicate was stirred at $4^{\circ} \mathrm{C}$ for $10 \mathrm{~min}$. After centrifugation, the supernatant was taken and proteins were precipitated by addition of ammonium sulfate to saturation. The ammonium sulfate pellet was resuspended in SB100 plus $6 \mathrm{M}$ urea and was dialyzed using Spectrapor 3 tubing against SB100. Precipitated protein was removed by centrifugation, and the supernatant was diluted to $50 \mathrm{mM} \mathrm{KCl}$ prior to loading onto a Bio-Rad Affigel Blue column (for LA57-N ${ }^{102 L}$ ) or a CM-Sephadex column (for $\mathrm{N}^{102 \mathrm{LT}}$ ). Peak fractions were collected and run on a Sephadex G75 (superfine) column. Peak fractions from this column were concentrated using an Amicon YM5 filter. The LA57$\mathrm{N}^{102 L T}$ protein fractions from the G75 column were purified with one step further by dialysis into SB 15 and chromotography on a CM-Sephadex column.

\section{Circular dichroism}

Circular dichroism measurements from 250 to $203 \mathrm{~nm}$ were taken using an AVIV model 60DS spectropolarimeter. Melting curves were obtained by measuring $[\theta]_{222}$ as a function of temperature as described by Hecht et al. (1984). For these studies protein concentrations were $50 \mu \mathrm{g} / \mathrm{ml}$ in $10 \mathrm{mM}$ potassium phosphate (pH 7.0), $100 \mathrm{~mm} \mathrm{KCl}$.

\section{Pulse-chase experiments}

Cultures of E. coli strain DP700, containing plasmids encoding wild-type or mutant variants of the amino-terminal domain, were grown at $37^{\circ} \mathrm{C}$ to an $\mathrm{OD}_{600}$ of $0.2-0.3$ in M9 minimal medium (Miller 1972), supplemented with each of the 20 naturally occurring amino acids except methionine and cysteine. Transcription from the $\mathrm{P}_{t a c}$ promoter was induced by the addition of $1 \mathrm{mM}$ IPTG. Twenty minutes after induction, cultures were pulse-labeled by addition of $37.5 \mu \mathrm{Ci}$ of $L-\left[{ }^{35} S\right]$ methionine (sp. act. $>800 \mathrm{Ci} / \mathrm{mmole} /$ per milliliter of cells. After $2 \mathrm{~min}$, excess unlabeled L-methionine (1.4 mg/ml cells) was added. At various times after this, $0.5-\mathrm{ml}$ portions of cells were removed and added to $35 \mu \mathrm{l}$ of an ice-cold mixture of protease inhibitors $\mid 60$ mM phenylmethylsulfonyl fluoride, $30 \mathrm{~mm} N$-ethylmaleimide, and $80 \mathrm{mM}$ sodium azide) in $90 \%$ ethanol. An unlabeled saturated culture of cells $(100 \mu l)$ was added to each sample to facilitate recovery of the labeled cells by centrifugation. Cells were lysed by boiling in $200 \mu \mathrm{l}$ of Laemmli sample buffer, and lysates were electrophoresed on $20 \%$ polyacrylamide SDS-urea gels (Ito et al. 1980). Gels were autoradiographed using Kodak X-
Omat film. Band intensities in autoradiograms were measured using an LKB 2202 UltroScan laser densitometer.

To measure approximate synthesis rates, cells were pulse-labeled for $2 \mathrm{~min}$, and $0.5-\mathrm{ml}$ portions were removed and processed as described above. Prior to loading on polyacrylamide SDS-urea gels, $2 \mu \mathrm{l}$ of each sample was added to $5 \mathrm{ml}$ of $\mathrm{Hy}$ drofluor (National Diagnostics) and counted using an LKB 1211 Rackbeta liquid scintillation counter. The volume of each sample loaded on the gel was adjusted to give a constant number of counts per lane.

\section{HSP induction experiments}

Cultures of DP700 cells bearing appropriate plasmids were grown at $37^{\circ} \mathrm{C}$ to an $\mathrm{OD}_{600}$ of $0.2-0.3$ in minimal medium as described for pulse-chase experiments. Transcription from the $\mathrm{P}_{\text {tac }}$ promoter was induced by the addition of $1 \mathrm{mM}$ IPTG. At intervals after addition of IPTG, 1-ml aliquots were removed to Falcon 2059 tubes at $37^{\circ} \mathrm{C}$ and pulse-labeled by addition of 37.5 $\mu \mathrm{Ci}$ of $\mathrm{L}-\left[{ }^{35} \mathrm{~S}\right]$ methionine (sp. act. $>800 \mathrm{Ci} / \mathrm{mmole}$ ) per milliliter of cells. After 2 minutes, incorporation of labeled methionine was stopped by transferring $0.5-\mathrm{ml}$ portions of cells to Eppendorf tubes that contained $25 \mu \mathrm{l}$ of unlabeled methionine $(28$ $\mu \mathrm{g} / \mu \mathrm{l})$ and $35 \mu \mathrm{l}$ of the protease mixture used in pulse-chase experiments. When synthesis of HSPs was monitored as a function of IPTG concentration, cultures were induced with IPTG for $30 \mathrm{~min}$ prior to pulse-labeling. Samples were processed as described for pulse-chase experiments, and lysates were loaded on $7.5 \%$ polyacrylamide gels (Laemmli 1970). Gels were autoradiographed, and band intensities were measured as described above.

Induction of heat shock proteins after a temperature increase was assayed as described above, except that IPTG was not added and cells were transferred to $42^{\circ} \mathrm{C}$ for $7 \mathrm{~min}$ prior to labeling with $\mathrm{L}-\left[{ }^{35} \mathrm{~S}\right] \mathrm{methionine}$.

\section{Western blot}

Estimates of the amount of LA57- $\mathrm{N}^{102 \mathrm{LT}}$ protein present in DP700 cells after a 30-min induction with various amounts of IPTG were obtained using Western blot analysis. Lysates from HSP induction experiments were electrophoresed on $15 \%$ polyacrylamide gels (Laemmli 1970), and Western blots were performed using polyclonal antisera raised against the aminoterminal domain of $\lambda$ repressor (Breyer 1988), essentially as described (Ausubel et al. 1989). Horseradish peroxidase conjugated donkey anti-rabbit IgG was used as a secondary antibody.

\section{Growth curves}

E. coli strain DP700 bearing the appropriate overproducing plasmid was grown at $37^{\circ} \mathrm{C}$ in $\mathrm{M} 9$ minimal medium (Miller 1972), supplemented with each of the 20 naturally occurring amino acids, except methionine and cysteine. Measurements of the $\mathrm{OD}_{600}$ were taken at intervals and when $\mathrm{OD}_{600}$ reached $0.2-0.3$ the cultures were split into two $5-\mathrm{ml}$ aliquots. One portion was induced with $1 \mathrm{mM}$ IPTG and the $\mathrm{OD}_{600}$ of both samples was monitored over the course of the next $90 \mathrm{~min}$.

\section{Acknowledgments}

We thank Jadwiga Wild for providing the $\mathrm{P}_{h t p G}-$ lacZ fusion, Carol Gross for supplying strains CAG2039 and CAG2041, Rich Breyer for plasmid pRB104 and antisera against the amino-terminal domain, Jim Bowie for the plasmid encoding the $\mathrm{N}^{102 \mathrm{LT}}$ protein, Peter Kim for use of the spectropolarimeter, 
and Jim $\mathrm{Hu}$ and Alan Grossman for critical reading of the manuscript. Discussions with Alan Grossman, Jim $\mathrm{Hu}$, Jim Bowie, and David Straus contributed greatly to the progress of this work. This work was supported by a National Institutes of Health grant 16892 and by a predoctoral grant (to D.A.P.) from the Keck Foundation.

\section{References}

Ausabel, F.M., R. Brent, R.E. Kingston, D.D. Moore, J.A. Smith, and K. Struhl. 1989. Current protocols in molecular cloning. Greene Publishing Associates and Wiley Interscience, New York.

Bahl, H., H. Echols, D.B. Straus, D. Court, R. Crowl, and C.P. Georgopoulos. 1987. Induction of the heat shock response of $E$. coli through stabilization of $\sigma^{32}$ by the phage $\lambda$ cIII protein. Genes Dev. 1: 57-64.

Bochkareva, E.S., N.M. Lissin, and A.S. Girshovich. 1988. Transient association of newly synthesized unfolded proteins with the heat-shock GroEL protein. Nature 336: 254-257.

Bowie, J.U. and R.T. Sauer. 1989. Identification of C-terminal extensions that protect proteins from intracellular proteolysis. J. Biol. Chem 264: 7596-7602.

Breyer, R.M. 1988. "Antibody interactions with the N-terminal domain of $\lambda$ repressor." Ph.D. thesis, Massachusetts Institute of Technology, Cambridge. Massachusetts.

Goff, S.A. and A.L. Goldberg. 1985. Production of abnormal proteins in $E$. coli stimulates transcription of lon and other heat shock genes. Cell 41: 587-595.

Goff, S.A., R. Voellmy, and A.L. Goldberg. 1988. Protein breakdown and the heat shock response. In Ubiquitin (ed. $M$. Rechsteiner|, pp. 207-238. Plenum Press, New York.

Grossman, A.D., J.W. Erickson, and C.A. Gross. 1984. The htpR gene product of $E$. coli is a sigma factor for heat-shock promoters. Cell 38: 383-390.

Grossman, A.D., D.B. Straus, W.A. Walter, and C.A. Gross. 1987. $\sigma^{32}$ synthesis can regulate the synthesis of heat shock proteins in Escherichia coli. Genes Dev. 1: 179-184.

Hecht, M.H., J.M. Sturtevant, and R.T. Sauer. 1984. Effect of single amino acid replacements on the thermal stability of the $\mathrm{NH}_{2}$-terminal domain of phage $\lambda$ repressor. Proc. Natl. Acad. Sci. 81: 5685-5689.

Ito, K., T. Date, and W. Wickner. 1980. Synthesis, assembly into the cytoplasmic membrane, and proteolytic processing of the precursor of the coliphage Ml3 coat protein. J. Biol. Chem. 255: 2123-2130.

Ito, K., Y. Akiyama, T. Yura, and K. Shiba. 1986. Diverse effects of the MalE-LacZ hybrid protein on Escherichia coli cell physiology. I. Bacteriol. 167: 201-204.

Laemmli, U.K. 1970. Cleavage of structural proteins during the assembly of the head of bacteriophage T4. Nature 227: 680685.

Magasanik, B. 1988. Reversible phosphorylation of an enhancer binding protein regulates the transcription of bacterial nitrogen utilization genes. Trends Biochem. Sci. 13: 475-479.

Maniatis, T., E.F. Fritsch, and I. Sambrook. 1982. Molecular cloning: A laboratory manual. Cold Spring Harbor Laboratory, Cold Spring Harbor, New York.

Maurizi, M.R., P. Trisler, and S. Gottesman. 1985. Insertional mutagenesis of the lon gene in Escherichia coli: lon is dispensable. J. Bacteriol. 164: 1124-1135.

Miller, J. 1972. Experiments in molecular genetics. Cold Spring Harbor Laboratory, Cold Spring Harbor, New York.

Neidhardt, F.C. and R.A. VanBogelen. 1987. Heat shock re- sponse. In Escherichia coli and Salmonella typhimurium (ed. F.C. Neidhardt), pp. 1334-1345. American Society for Microbiology, Washington, D.C.

Neidhardt, F.C., R.A. VanBogelen, and V. Vaughn. 1984. The genetics and regulation of heat-shock proteins. In Annual reviews of genetics (ed. H.L. Roman, A. Campbell, and L. M. Sandler!, pp. 295-329. Annual Reviews, Palo Alto, California.

Pabo, C.O. and M. Lewis. 1982. The operator-binding domain of $\lambda$ repressor-structure and DNA recognition. Nature 298: $443-447$.

Parsell, D.A. and R.T. Sauer. 1989. The structural stability of a protein is an important determinant of its proteolytic susceptibility in E. coli. J. Biol. Chem. 264: 7590-7595.

Sanger, F., S. Nicklen, and A.R. Coulson. 1977. DNA sequencing with chain terminating inhibitors. Proc. Natl. Acad. Sci. 74: 5463-5467.

Sauer, R.T. and R. Anderegg. 1978. Primary structure of the lambda repressor. Biochemistry 17: 1092-1100.

Sauer, R.T., K. Hehir, R.S. Stearman, M.A. Weiss, M.A. JeitlerNilsson, E.G. Suchanek, and C.O. Pabo. 1986. An engineered intersubunit disulfide enhances the stability and DNA binding of the amino-terminal domain of $\lambda$ repressor. Biochemistry 25: 5992-5998.

Straus, D.B., W.A. Walter, and C.A. Gross. 1987. The heat shock response of $E$. coli is regulated by changes in the concentration of $\sigma^{32}$. Nature 329: 348-351.

VanBogelen, R.A., P.M. Kelley, and F.C. Neidhardt. 1987. Differential induction of heat shock, SOS, and oxidative stress regulons and accumulation of nucleotides in Escherichia coli. J. Bacteriol. 169: 26-32.

Vershon, A.K., K. Blackmer, and R.T. Sauer. 1986. Mutation of the Arc repressor using synthetic primers with random nucleotide substitutions. In Protein engineering (ed. M. Inouye and R. Sarmal, pp. 243-256. Academic Press, Orlando, Florida. 


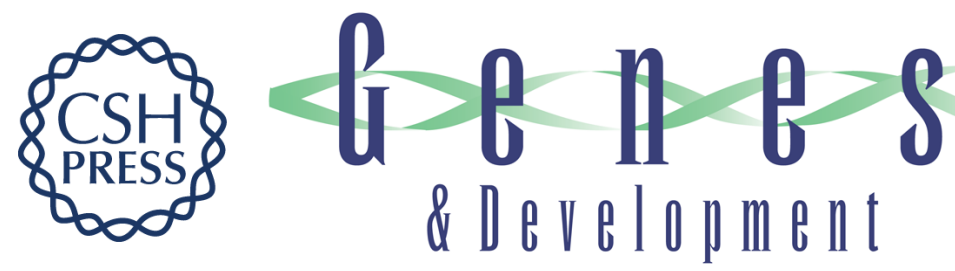

\section{Induction of a heat shock-like response by unfolded protein in Escherichia coli: dependence on protein level not protein degradation.}

D A Parsell and R T Sauer

Genes Dev. 1989, 3:

Access the most recent version at doi:10.1101/gad.3.8.1226

References This article cites 19 articles, 10 of which can be accessed free at: http://genesdev.cshlp.org/content/3/8/1226.full.html\#ref-list-1

License

Email Alerting Service

Receive free email alerts when new articles cite this article - sign up in the box at the top right corner of the article or click here.

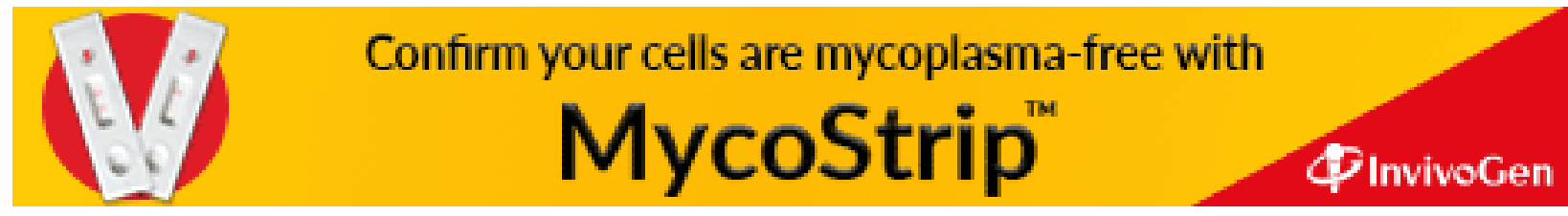

